\title{
Benefits in the Implementation of Safety, Health, Environmental and Quality Integrated System
}

\author{
Karla M. P. Carvalho, Flávio Picchi, Gladis Camarini, and Edna M. Q. O. Chamon
}

\begin{abstract}
This article aims to present the benefits in the implementation of the integrated management system based on the standards ISO 9001, ISO 14001 and OHSAS 18001. It is a case study in a sector of the construction industry chain, located in the southeastern Brazil. An exploratory study using a questionnaire with leaders from this particular industry was conducted, as well as a documentary analysis from the Integrated Management System (IMS) archives. The obtained results of the documentary analysis and perceptions of leaders survey were observed based on previous IMS research. The results indicated that almost all leaders identify several benefits in systems integration, with an improvement in the routine management as the main benefit, and the financial savings as the smallest benefit. It was also found that in leader perception the most of IMS documents are integrated. The same result was found in many documents in the documentary analysis.
\end{abstract}

Index Terms-Integrated management system, ISO 9001, ISO 14001, OHSAS 18001, steel company.

\section{INTRODUCTION}

The IMS (Integrated Management System) studied here consists of four systems: safety, health, environment and quality systems that are integrated.

According to Simon et al. [1], the ISO 9001 has 1,064,785 companies registered in more than 170 countries; and ISO 14001 has 223,149 certificates companies in more than 150 countries. Araujo e Rodrigues [2] reported that OHSAS 18001 was officially published in 1999 . The OHSAS 18001 was the last one published, and has shown a constant evolution in a number of companies seeking implantation [1].

Many studies on the IMS implementation have been published, but few studies have been conducted looking for to identify the benefits of deploying the systems in the perspective of leaders directly related to the industrial production process.

This study aims to identify the perceived benefits by leaders in the implementation of the integrated management system and to analyze the level of integrating some items from IMS through a case study in a supply chain of the construction industry.

\footnotetext{
Manuscript received May 30, 2014; revised July 23, 2014. This work was supported in part by the School of Civil Engineering and Urban Design at University of Campinas, UNICAMP, and by the National Counsel of Technological and Scientific Development - CNPq - Brazil.

Karla M. P. Carvalho, Flávio Picchi, and Gladis Camarini are with Civil Engineer College at the State University of Campinas - UNICAMP, Campinas, Brazil (e-mail: karla.p.carvalho@uol.com.br, fpicchi@lean.org.br, gcamarini@gmail.com, camarini@fec.unicamp.br ).

Edna M. Q. O. Chamon is with the Taubaté University -UNITAU, Taubaté, Brazil (e-mail: edna.chamon@gmail.com).
}

\section{LITERATURE}

The integrated management system can be understood as a set of interrelated processes that share human resources, information, materials, infrastructure, financial resources. The IMS is organized in order to meet goals related to satisfying different stakeholders [3].

The Quality Management System (QMS) is defined by the NBR/ISO 9001 [4] and describes the quality management as a set of activities and tools, coordinated to guide and control the company in attention to the quality of its products and services according to the customer, the company and stakeholders requirements. These requirements shall be established, and described in the organizational policies, objectives and procedures.

The QMS implementation can provide many benefits for the organization, such as customers satisfaction, not only by improving the quality of the product, but also for better understanding their needs, reducing the complaints and the nonconforming products; reducing the spending time on rework due to errors in the process or poor quality of raw materials; more effective internal and external communications; involvement and satisfaction of the employees; stabilization of the processes, and increasing the profit of the company.

The Brazilian Standards [4] define a process and systemic approach based on four structural points, namely: understanding and meeting the requirements (customer, company and stakeholders requirements), the need to consider the processes in terms of added value, obtaining results in performance and efficiency of the process, and continuous improvement of the processes based on objective measurements.

The Environmental Management System (EMS) aims to identify the environmental aspects, defining a set of tools to control the occurrence of environmental impacts as well as improving the use of natural resources in order to promote sustainability [5].

According to Oliveira [6], the ISO 14001 [5] does not define the criterion levels of development neither the management system performance, different from other standards and certifications. The ISO 14001 [5] presents the requirements for the deployment of an environmental management system following the cycle PDCA (Plan, Do, Check and Act) to develop and implement policies and objectives which encompasses legal requirements and information about significant environmental aspects, allowing the balance of the environmental protection and the pollution prevention with the socioeconomic needs.

One of the main benefits of the implementation and certification of ISO 14001 is to improve the image of the 
company, opening to national and international markets, increasing customer satisfaction, following the legislation, and mainly, making the protection and improvement of the environmental conditions [6].

The Management System of Occupational Health and Safety (MSOHS) has the purpose to identify hazards, risk assessment and control, in order to avoid injury and illnesses in people. The Standard OHSAS 18001 is a relatively new and was officially published in 1999 with the goal of developing the first certification and a guidance standard for the implementation of a MSOHS [2].

Carvalho and Chamon [7] found that one of the main benefits of deploying the safety management system is the decrease of the frequency and severity rates of accidents through appropriate control of the risks in the workplaces and in the developed activities. Other benefits such as decrease in costs after accidents and occupational diseases, worker satisfaction, social responsibility, corporate image and decreasing of interruptions in production are also presented in several researches [1]-[3].

Integrating the systems of quality, safety, health and environment can bring many benefits to the company and the employees. Oliveira [6] shows as the biggest gains in the company: synergy in execution of common tasks, cost reduction, improving the company image, bureaucracy reduction, and reducing the duplication of tasks.

Simon and Karapetrovic [1] worked on the benefits and difficulties of integrating the systems. They used a questionnaire which was sent to 176 companies in Catalonia, Spain. They reported several benefits in integrating e.g.: increase in employee motivation, higher collaboration, increase in organizational efficiency, increase in organizational culture, improvement of the organizational strategy, the communication, and company image, and also better use of the results of internal and external audit.

As the major difficulties to integrate all systems, Vitoreli and Carpinetti [8] report: shortage of human resources for deployment, lack of collaboration between departments, lack of specialized auditors, lack of motivation and different models of each Standard, the latter being identified in the majority of the researches.

According to Bernardo et al. [9] there is no single model that is suitable for all organizations, academic research has various models of integration at different levels. Regarding the integration system, Karapetrovic [10] reports that there are three types of organizations: those that have only integrated documentation, those with integrated processes, objectives and capabilities, and those which have all the parts of an integrated management system in a single management system.

Karapetrovic [10] further defines only two levels of integrations, fully integrated or partially integrated. Jorgensen et al. [11] present three levels: 1 - corresponding (increase compatibility with references between parallel systems), 2 - coordinated and coherent (generic process focusing the management of the task cycle) and 3 - strategic and inherent (organizational culture learning, continuous improvement of performance and involvement of the stakeholders related to internal and external challenges).

An empirical study by Bernardo et al. [9] show that the level of the Internal Audit integration is directly related to the level of integration of the management system.

Regarding the integration of the internal audit Bernardo et al. [12] divided into:

- Not integrated: Internal audit is conducted by different teams, which are designed separately, and have different reports.

- Partially integrated: Usually the Audit is conducted by a single team or performed simultaneously, but only for some items on the management system. Normally there is a single planning, but different reports.

- Fully integrated: The audit is performed by a single team and / or performed simultaneously, there is a single planning and it is issued in a single report.

\section{METHOD}

This case study was conducted in three units of a large steel industry, located in the southeastern region of Brazil. The surveyed units produce steel in the form of screens, trusses and rebar for use in construction and other steel products such as bars. The total number of employees in the three units studied is approximately 1,000, and there are 35 leaders. The researched industry has different features from the civil construction sector that affect the implementation and maintenance of the IMS. The main ones are low employee turnover and training school (all employees have at least completed high school).

The unit began the management system with the implantation of QMS, followed by ISO 9001 accreditation. The second implanted management system was the safety system without the accreditation system. It was developed on the basis of Management System Losses presented by DNV (Det Norske Veritas). The EMS was the last system to be deployed with the unit, but by the market pressure it has been certified by the ISO 14001 prior to occupational health and safety system. The certification of the occupational health and safety system was the last to be certified and the implementation of OHSAS 18001 came along with the integration of the systems that occurred in 2012.

To identify the benefits in deploying IMS perceived by the leaders in this particular industry, an exploratory survey was conducted using questionnaires with closed and open questions. For creating the questionnaire a survey was conducted by a literature research in the database SciVerse Scopus, using as filter the latest publications and the topic of integrated management system related to ISO 9001, ISO 14001 and OHSAS 18001 standards. The main authors for the preparation of the questionnaire were [11]-[14]. The questions were divided into three categories: benefits of IMS; difficulty in integrating the systems; and management system documents.

Each unit has a manager to manage the safety, health and environment process, and another manager in the quality control process. According Vitoreli and Carpinetti [8] there is little research on the subject and in the literature the results show that there is no consensus on the importance of having a single manager for all the processes. Some authors reported difficulties in the IMS implantation due to problems of relationship between departments [6], [10], [15].

Thirty questionnaires were sent to unit leaders of the 
investigated industry, namely, direct leaders and leaders of leaders. Table I show the leader's areas and number of respondents.

\begin{tabular}{lc} 
TABLE I: RETURNED QUESTIONARY IN EACH AREA AND QUANTITY \\
\hline \hline Area & Questionaries \\
\hline Safety and Environment & 2 \\
Quality & 1 \\
Maintenance & 1 \\
Operations & 2 \\
Logistics & 1 \\
Other Areas from Administrative Sector & 3 \\
\hline \hline
\end{tabular}

Questionnaires were sent using the Google Docs, available at www.docs.google.com/forms. Twenty questionnaires returned. In addition to the questionnaire, it was performed the analysis of key documents and items that compose the IMS system: management, policies, objectives and targets, responsibilities, resources, operating procedures, management review, corrective and preventive action, training manual system, internal and external audit in order to verify the level of integration between documents.

The questionnaires evaluated: time company and leader role, benefits and difficulties in the integration of management systems, and perceptions of leaders as the integration of document management system.

To define the integration level of the documents, it was used those defined by Bernardo et al. [12] and França e Picchi [13]: fully integrated, partially integrated or not integrated.

The questionnaires were analysed and the quantitative and qualitative responses (closed and open respectively) were compared to the results obtained in the documentary analysis and also with other results obtained in published works.

\section{RESUlTS AND ANALYSIS}

From the returned questionnaires we had the following results:

- Leaders: $60 \%$ work more than 10 years in the company, $30 \% 5-10$ years and $10 \%$ less than 2 years.

- The time as a leader: $60 \%$ are in this position from 2 to 5 years, $30 \%$ from 5 to 10 and $10 \%$ over 10 years.

The majority of the leaders $(90 \%)$ have been working for over 5 years in the company, but more than $60 \%$ are in this position less than 5 years.

The longtime business can be a favorable point in the integration of systems, considering the leaders experience with the existing tools and documents of the company, which is part of each Standard.

\section{A. Benefits of Integrating Systems}

The perceived benefits with the IMS by the company leaders, $90 \%$ said they have many benefits. Only $10 \%$ believe they have just a few benefits.

In an opened question about the main benefits of IMS, the answers were: a single audit, optimization in system analysis, synergy, deployment to operation, only one critical analysis, control actions in one place, simplifying, unifying goals and consequently greater focus on results, less time of meeting, fewer procedures, and increasing of operational worker participation. Simon et al. [1] Obtained similar results in their research on the benefits and difficulties of IMS.

Regarding the benefits of integrating systems with leading management, $100 \%$ agreed that there was a benefit, and $40 \%$ answered that they fully agreed, and $60 \%$ agreed. As an example of the benefits in the routine management it appeared:

- It is easier to manage when it comes to one system;

- Less audit time;

- Less meeting time;

- When the leader is in the area, he can look at all systems (leader answer: "When I treat one Management Modification or failure, all points related to environment are checked, safety, quality [...]");

- Document control;

- Organization of training; and

- The simplification in the agenda.

- Vitoreli and Carpinetti [8] report: training unification, better use of financial resources and unification of internal and external audit as key benefits. Jorgensen et al. [11] show reduced charges of management by improvements in internal conditions as a main benefit.

Related to leader routine management, $90 \%$ of leaders agreed that integration of systems reduces the needed time to invest in management, and only one leader disagreed with this benefit. Similar results were obtained to financial savings for the company ( $80 \%$ agree or totally agreed, $10 \%$ disagreed and $10 \%$ did not answer the question).

Many researchers present financial savings as a benefit in the integration of the system [6], [9], [16]. 90\% of the leadership agreed that the time spent in the routine management decreased after the integration of the systems.

The leaders perception leaders in relation to financial benefits, $20 \%$ totally agreed, $60 \%$ agreed, 15\% did not know and $5 \%$ disagreed. This item appears as the best benefit for only $5 \%$ of the leaders. In the opinion of the respondents, the economy of audits time, spent time in management, and better management are the best benefits of the integrating systems.

Almost all leaders agreed that the operational area obtained benefits with the systems integration (50\% strongly agreed, $45 \%$ agreed). Only one leader disagreed that the operational area had benefits.

The leaders described the following perceived benefits:

- Understanding of the system;

- Fewer audits;

- integrated procedures;

- focusing on activities;

- ease in understanding of integrated policy;

- Overview of the entire system;

- Control of documents;

- Organization of training and auditing;

- Centralization of information;

- Better pendency management;

- unified standards;

- integrated policy;

- Single audit;

- Integrated forms.

The results of Fresner and Engelhardt [14] reinforce the 
leader's affirmative, whereas the segregated systems do not help the employees because they need to work with the three systems. For Fresner and Engelhardt [14] it does not matter who defines system requirements. It is necessary to understand that employees work simultaneously with them and not in a segregated form.

Table II summarizes the objective questions about the benefits of the integrated management system implementation, according to the leaders' answers.

\section{B. Difficulties of Integrating Systems}

For the leaders, the main barrier in systems integration is the relationship between the managers of the process quality, safety, health and environment.

Simon et al. [1] also describes the lack of collaboration between departments, such as difficulty in integrating systems. To Simon et al. [1] interaction between departments of the systems is crucial to have success in the integration implantation. Managers need to understand these examples, and think in a systemic way without being afraid of losing practices and reconcile the demands of all areas. The relationship between the managers of the process often appeared in response to the opened question: "In your opinion, what are the main difficulties of integrating systems quality, safety, health and the environment?"

The initial fitting process to the integrated system also appears difficult, however the report after a period of management adaptation becomes easier, because according to the survey, all information is practically on the same place. Simon et al. [1] suggest that the lack of employee motivation appears as the main difficulty in integrating systems, followed by certification standard items, such as the difference between common elements of the standard and different models of system implantation.

The difference between the common elements of the Standard and the different models of the system implantation was not identified by this survey, neither by the quality process manager, nor the HSE (Health, Safety and Environment) process manager. There are leaders that did not identify difficulties in the system integration.

\section{Document's Integration}

Simon et al. [1] presents an inadequate integration in the management system documents as one of the main barriers for an appropriate management.

TABLE II: OBJECTIVE QUESTIONS ANSWERS ABOUT THE BENEFITS

\begin{tabular}{lcccc}
\hline \hline & $\begin{array}{c}\text { Helped in } \\
\text { managing } \\
\text { the day by } \\
\text { day? }\end{array}$ & $\begin{array}{c}\text { Decrease } \\
\text { your time } \\
\text { need to } \\
\text { invest in } \\
\text { management } \\
\text { ? }\end{array}$ & $\begin{array}{c}\text { Generated } \\
\text { financial } \\
\text { savings for } \\
\text { the } \\
\text { company? }\end{array}$ & $\begin{array}{c}\text { Operational } \\
\text { area had the } \\
\text { benefit of the } \\
\text { integration? }\end{array}$ \\
\hline $\begin{array}{l}\text { Totally } \\
\text { agreed }\end{array}$ & $40 \%$ & $50 \%$ & $20 \%$ & $50 \%$ \\
$\begin{array}{l}\text { Agreed } \\
\text { Disagree } \\
\text { d }\end{array}$ & $60 \%$ & $40 \%$ & $60 \%$ & $45 \%$ \\
$\begin{array}{l}\text { Totally } \\
\text { disagreed }\end{array}$ & $0 \%$ & $10 \%$ & $5 \%$ & $5 \%$ \\
$\begin{array}{l}\text { I don't } \\
\text { know }\end{array}$ & $0 \%$ & $0 \%$ & $0 \%$ & $0 \%$ \\
\hline \hline
\end{tabular}

Fig. 1 presents the documentary review results and similar research about the documents of the IMS. In documentary analysis, it was checked:
- Policies;

- Management manual;

- Objectives and goals;

- Internal communication;

- Resources and provisions;

- Trainings;

- Operational procedures;

- Responsibilities;

- Critical analyses;

- Preventive and corrective actions;

- Nonconformities;

- Internal and external audit.

In the analyzed items, about their total integration, only internal communications and provision of resources did not obtain a total perception of the leaders.

The goals and objective items, external communication, training, critical analysis, action-corrective, preventive action and nonconformity were defined as partially integrated into the documentary analysis.

Although the critical analysis, corrective action, preventive action and nonconformities were analyzed how partially integrated, in the leaders perception these items are totally integrated. This leaders' perception can occur because:

1) The critical analysis is performed at the same time, although Standard items in the critical analysis report are not integrated. The HSE items are fully integrated but in the quality, only a few are integrated. Usually, leaders participate in the critical analysis meeting, but there is no focus on the report.

2) Corrective-action, preventive action and nonconformities: it uses the same software for communication and recording, but these items are analyzed using different methods.

In Fig. 1 it is possible to see that most of documents and practices in the researched company behaves in the similar way than other companies. Some items as critical analyses were assessed as partially integrated. Bernardo [12] and Oliveira [6] researches evaluated them item as totally integrated into almost all researched companies.

Preventive and corrective actions were analyzed as partially integrated. The companies researched by Oliveira [6] found only $12 \%$ having this document totally integrated and Bernardo [12] had 50\% in his research.

External audit is integrated in this survey, but in the Oliveira's research [6] most of the companies do not still realize the integrated external audit. Bernardo's research [12] did not analyze this item.

The external audit, main item not integrated with other studies [6]-[14], probably is the last item to be included in the integration process. It is important to highlight that integrated external audit was the most financial benefit observed by the leaders in this survey.

No integrated items were identified in this survey. However, as it can be seen in Fig. 1, there are several companies that look for implementing management systems and they still have important documents such as, policies and manual that are not integrated. The lack of proper integration of documents appears in several researches as an important barrier in the IMS implementation [9], [11], [14]. 


\section{Integrated Documents of IMS}

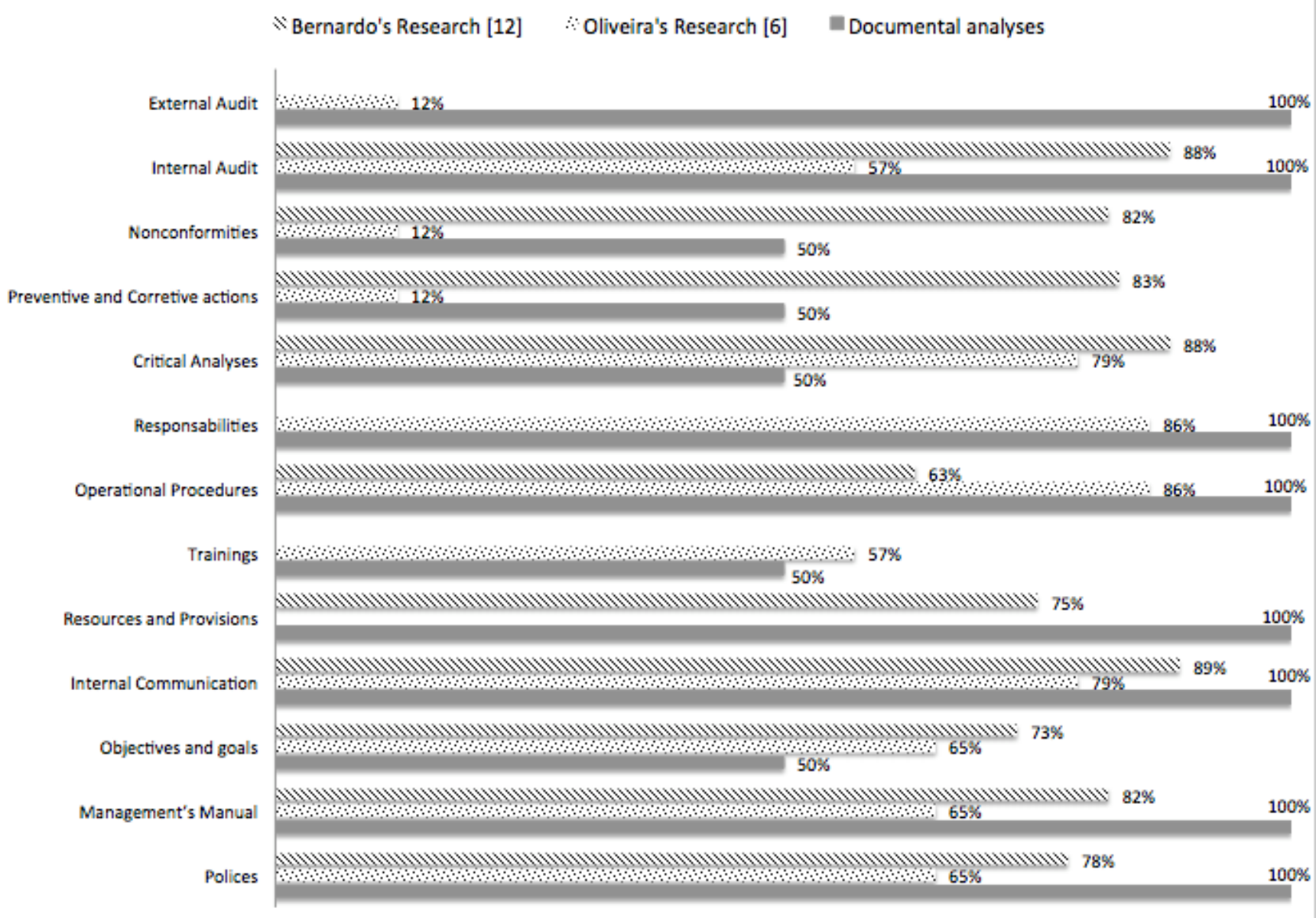

Fig. 1. Integrated document of IMS - documental analysis and researches.

\section{CONCLUSIONS}

In the company where the survey took place it was observed that, in the perception of the leaders, the key documents of the IMS are integrated, even as the documentary analysis. This analysis identified some documents partially integrated and any documents not integrated.

All leaders identify that the integration of the quality system, environmental and safety systems have brought many benefits. An improvement in the routine management is the main benefit, and financial benefit as the lowest important in their perception.

The leading barriers for IMS implantation, by the leaders perception, are the relationship between managers and initial fitting processes. Similar results were obtained in other surveys.

Suggestion to maximize the benefits of IMS, for this company, that has different managers for the quality and HSE processes, to analyze if the items described as partially integrated could be affected by the lack of a single manager.

\section{REFERENCES}

[1] A. Simon, S. Karapetrovic, and M. Casadesus, "Difficulties and benefits of integrated management systems," Industrial Management \& Data Systems Journal. vol.112, no. 5, pp. 828-846, 2012.

[2] N. Araújo and C. Rodrigues, "Sistema da segurança baseado na OHSAS 18001, para empresas construtoras," III SIBRAGEC -
Simpósio Brasileiro de Gestão e Economia da Construção, UFSCar, São Carlos, SP, 16 a 19 de Setembro de, 2003.

[3] S. Karapetrovic and W. Willborn, "Integration of quality and environmental systems," The TQM Magazine, vol. 10, no. 3, pp. 204-213, 1998.

[4] ABNT, Associação Brasileira de Normas Técnicas, "NBR ISO 9000: 2000. Sistemas de gestão da qualidade - Fundamentos e vocabulário," Rio de Janeiro: ABNT, 2000.

[5] ABNT, Associação Brasileira de Normas Técnicas, "NBR ISO 14001: 2004. Sistemas de gestão ambiental - Especificacões e diretrizes para uso," Rio de Janeiro: ABNT, 2004.

[6] O. Oliveira, "Guidelines for the integration of certifiable management systems in industrial companies," Journal of Cleaner Prodution, no. 57, pp. 124-133, 2013.

[7] K. Carvalho and E. Chamon, "Representacão social do risco: um estudo na indústria siderúrgica," Revista Psicologia e Saber Social, vol.1, no. 1, pp. 140-148, 2012.

[8] G. Vitoreli and L. Carpinetti, "Análise integrada dos sistemas de gestão normalizados ISO 9001 e OHSAS 18001: estudo de casos múltiplos," Revista Gestão \& Produção, São Carlos, vol. 20, no. 1, pp. 204-217, 2013.

[9] M. Bernardo, M. Casadesus, S. Karapetrovic, and I. Heras, "How integrated are environmental, quality and other standardized management systems? An empirical study," Journal of Cleaner Production, no. 17, pp. 742-750, 2009.

[10] S. Karapetrovic, "Musings on integrated management systems,"Measuring Business Excellence, vol. 7, no. 1, pp. 4-13, 2003.

[11] T. Jorgensen, A. Remmen, and M. Mellado, "Integrated management systems - three different levels of integration," Journal of Cleaner Production, no. 14, pp. 713-722, 2006.

[12] M. Bernardo, M. Casadesus, S. Karapetrovic, and I. Heras, "An empirical study on the integration of management system audits," Journal of Cleaner Production, vol.18, pp. 486-495, 2010.

[13] N. França and F. Picchi, "Sistema integrado de gestão - qualidade, meio ambiente, segurança e Saúde: recomendações para implementação em empresas construtoras de Edifícios," M.Sc. thesis, Universidade de Campinas, Campinas, SP, 2009. 
[14] J. Fresner, G. Engelhardt, "Experiences with integrated management systems for two small companies in Austria," Journal of Cleaner Production, vol. 12, pp. 623-631, 2004.

[15] S. Karapetrovic and M. Casadesus, "Implementing environmental with other standandardized management systems: Scope, sequence, time and integration," Journal of Cleaner Production, vol. 17, pp. 533-540, 2009.

[16] L. Pheng and C. Pong. "Integrating ISO 9001 and OHSAS 18001 for Construction," Journal of Construction Engineering and Management. vol. 129, pp. 338-347, 2003.

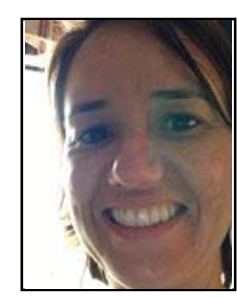

Karla M. P. Carvalho is a civil engineer at Mackenzie University. She did a specialization in safety at the University of Sao Paulo (USP), and in Technology and Environmental Management at Armando Alvares Penteado School (FAAP). She had a MBA in business management at Getulio Vargas Foundation (FGV).

She received her master degree (2012) at Taubate University, and she is a PhD student at School of Civil Engineering, Architecture and Urban Design,

University of Campinas.

Flávio Augusto Picchi is a civil engineer and as an assistant professor a School of Civil Engineering, Architecture and Urban Design, University of Campinas. He had his master degree and $\mathrm{PhD}$. degree at University of São Paulo. He is the director of the lean Institute Brazil. He has experience in civil engineering with emphasis on quality management and productivity. His research interest is the following subjects: lean thinking, quality management, construction, waterproofing and standardization. He has extensive experience in various industrial sectors in the implementation of the concepts of lean thinking.

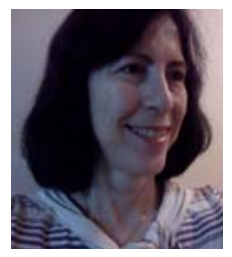

Gladis Camarini is a civil engineer and a professor at School of Civil Engineering, Architecture and Urban Design, University of Campinas. She had her master degree in 1988 and $\mathrm{PhD}$. degree in 1995 at University of São Paulo. She did postdoctoral studies at the Laboratoire des Materiaux et Durabilité des Constructions (LMDC) at Institut National des Sciences Apliquées (INSA, Toulouse, France, 1998). She also did postdoctoral studies at the National Institute for Space Research (INPE, São José dos Campos, Brazil, 2008). Then she also did postdoctoral studies at the Institute of Science and Technology del Hormigón (ICITECH), the Polytechnic School of Valencia (UPV) (Valencia, Spain, 2012). She is a peer reviewer of scientific journals indexed on the Journal Citation Reports, national and international journals, Congress and Seminars, and Brazilian Research Foundations. She is an IACSIT senior member. Her research interests include: building materials, mineral binders, mortars, industrial and construction wastes, reusing and recycling of materials, mortar, concrete, and other composites.

Edna Maria Querido de Oliveira Chamon was born in Cunha, São Paulo, Brazil. Edna Chamon has a PhD in psychology from the University of Toulouse, France, in 1998, and post-doctorate in education from the University of Campinas, Brazil, in 2003.

She is an assistant professor at the Department of Economics, Accounting and Administration, University of Taubaté, São Paulo, Brazil, where she coordinates the graduate program in human development and the graduate program in education. She was a visiting professor in the Department of Psychology at the University of Toulouse Jean Jaurès, Toulouse, France, in 2001. Her current research interests include social psychology, identity, and social representation, with applications to education.

Dr. Chamon is CNPq Researcher Level 2. 